\title{
CONTENTS OF VOLUME 44
}

R. P. AGARWAL and S. HEIKKILÄ: On the solvability of first-order discontinuous scalar initial and boundary value problems

PETER AIZENGENDLER: Newton's diagram method for nonlinear equations with several small parameters

G. K. ALDIS: See P. BROADBRIDGE

HORST ALZER: Inequalities for the beta function of $n$ variables

E. ARGYROPOULOS, D. GINTIDES and K. KIRIAKI: On the condition number of integral equations in linear elasticity using the modified Green's function

ROMAN BADORA, ROMAN GER and ZSOLT PÁLES: Additive selections and the stability of the Cauchy functional equation

N. S. BARNETT, S. S. DRAGOMIR and C. E. M. PEARCE: A quasi-trapezoid inequality for double integrals

M. G. BIN-SAAD: See H. M. SRIVASTAVA

HILARY BOOTH: Nonlinear electron solutions and their characteristics at infinity

B. H. BRADSHAW: See P. BROADBRIDGE

P. BROADBRIDGE, B. H. BRADSHAW, G. R. FULFORD and G. K. ALDIS: Huxley and Fisher equations for gene propagation: An exact solution

P. K. CHAUDHURI and SUBHANKAR RAY: Effects of an axisymmetric rigid punch on a nonhomogeneous transversely isotropic half-space

CAILIAN CHEN: See XINPING GUAN

QIHONG CHEN: Minimax control of an elliptic variational bilateral problem

BONG DAE CHOI and BARA KIM: $M / G / 1$ queueing system with fixed feedback policy

ASHA CHOPRA: See RAJNEESH KUMAR

\section{CHRISTOPHER M. COSGROVE: See N. S. WITTE}

R. M. CULLEN, A. KOROBEINIKOV and W. J. WALKER: Seasonality and critical community size for infectious diseases

M. DANIEL: See V. VEERAKUMAR

R. L. DEWAR: Asymptotology-a cautionary tale

S. S. DRAGOMIR: See N. S. BARNETT

DE-XING FENG: See DONG-HUA SHI

L. K. FORBES: See G. C. HOCKING

P. J. FORRESTER: See N. S. WITTE

DANIEL FRANCO and RODRIGO L. POUSO: Nonresonance conditions and extremal solutions for first-order impulsive problems under weak assumptions

D. S. FRANZBLAU and A. RAYCHAUDHURI: Optimal Hamiltonian completions and path covers for trees, and a reduction to maximum flow

G. R. FULFORD: See P. BROADBRIDGE 
HONGJUN GAO and KENG-HUAT KWEK: Global existence for the generalised 2D Ginzburg-Landau equation

ROMAN GER: See ROMAN BADORA

D. GINTIDES: SEe E. ARGYROPOULOS

K. GOPALSAMY: See S. MOHAMAD

S. P. GOYAL: See K. C. GUPTA

B. GRAMMATICOS: See A. RAMANI

XINPING GUAN, YICHANG LIU, CAILIAN CHEN and PENG SHI: Observer-based robust $H_{\infty}$ control for uncertain time-delay systems

PARTHA GUHA: Diffeomorphisms on $S^{1}$, projective structures and integrable systems

K. C. GUPTA, S. P. GOYAL and ROHIT MUKHERJEE: Some results on generalized Voigt functions

PATRICK HABETS and RODRIGO L. POUSO: Examples of the nonexistence of a solution in the presence of upper and lower solutions

M. S. HARMER: Inverse scattering for the matrix Schrödinger operator and Schrödinger operator on graphs with general self-adjoint boundary conditions

S. HEIKKILÄ: See R. P. AGARWAL

JARMO HIETARINTA: Taming the movable singularities

G. C. HOCKING, J.-M. VANDEN-BROECK and L. K. FORBES: A note on withdrawal from a fluid of finite depth through a point sink

P. G. HOWLETT, C. E. M. PEARCE and A. P. TOROKHTI: An optimal linear filter for random signals with realisations in a separable Hilbert space

XING-BIAO HU and JOHAN SPRINGAEL: A Bäcklund transformation and nonlinear superposition formula for the Lotka-Volterra hierarchy

BARA KIM: See BONG DAE CHOI

K. KIRIAKI: See E. ARGYROPOULOS

A. KOROBEINIKOV: See R. M. CULLEN

N. A. KUDRYASHOV and M. B. SOUKHAREV: Discrete equations corresponding to fourthorder differential equations of the $P_{2}$ and $K_{2}$ hierarchies

RAJNEESH KUMAR, SUSHIL K. TOMAR and ASHA CHOPRA: Reflection/refraction of SH-waves at a corrugated interface between two different anisotropic and vertically heterogeneous elastic solid half-spaces

KENG-HUAT KWEK: See HONGJUN GAO

H. C. LAI and J. C. LIU: Minimax fractional programming involving generalised invex functions

VY KHOI LE: On some noncoercive variational inequalities containing degenerate elliptic operators

P. G. L. LEACH: See M. C. NUCCI

JYH-HAO LEE: See OKTAY K. PASHAEV

HUAN-WEN LIU and SONG-PING ZHU: The dual reciprocity boundary element method for magnetohydrodynamic channel flows

J. C. LIU: See H. C. LAI

YICHANG LIU: See XINPING GUAN

WEN-XIU MA and YUNBO ZENG: Binary constrained flows and separation of variables for soliton equations 
T. R. MARCHANT: Numerical solitary wave interaction: the order of the inelastic effect

M. MATIC, C. E. M. PEARCE and J. PECARIĆ: Two-point formulae of Euler type

S. MOHAMAD and K. GOPALSAMY: Extreme stability and almost periodicity in continuous and discrete neuronal models with finite delays

ROHIT MUKHERJEE: See K. C. GUPTA

M. C. NUCCI and P. G. L. LEACH: Symmetry analysis of and first integrals for the continuum Heisenberg spin chain

ZSOLT PÁLES: See ROMAN BADORA

J.-Y. PARLANGE: See S. W. WEEKS

OKTAY K. PASHAEV and JYH-HAO LEE: Black holes and solitons of the quantized dispersionless NLS and DNLS equations

M. A. PATHAN: See H. M. SRIVASTAVA

C. E. M. PEARCE: See N. S. BARNETT

C. E. M. PEARCE: See P. G. HOWLETT

C. E. M. PEARCE: See M. MATIĆ

J. PEČARIĆ: See M. MATIĆ

RODRIGO L. POUSO: See DANIEL FRANCO

RODRIGO L. POUSO: See PATRICK HABETS

A. RAMANI and B. GRAMMATICOS: What is the discrete analogue of the Painleve property?

SUBHANKAR RAY: See P. K. CHAUDHURI

A. RAYCHAUDHURI: See D. S. FRANZBLAU

G. C. SANDER: See S. W. WEEKS

W. K. SCHIEF: On the geometry of the Painlevé V equation and a Bäcklund transformation

DONG-HUA SHI and DE-XING FENG: Exponential decay rate of the energy of a Timoshenko beam with locally distributed feedback

PENG SHI: See XINPING GUAN

M. B. SOUKHAREV: See N. A. KUDRYASHOV

JOHAN SPRINGAEL: See XING-BIAO HU

H. M. SRIVASTAVA, M. A. PATHAN and M. G. BIN-SAAD: A certain class of generating functions involving bilateral series

Y. M. STOKES: Determining rotational deformity in broken forearms

YOSHITSUGU TAKEI: On an exact WKB approach to Ablowitz-Segur's connection problem for the second Painlevé equation

SUSHIL K. TOMAR: See RAJNEESH KUMAR

A. P. TOROKHTI: See P. G. HOWLETT

J.-M. VANDEN-BROECK: See G. C. HOCKING

PETER J. VASSILIOU: An integrable system of partial differential equations on the special linear group

V. VEERAKUMAR and M. DANIEL: Propagation of an electromagnetic soliton in a ferromagnetic medium

W. J. WALKER: See R. M. CULLEN

ZHICHENG WANG: See XIANZHANG WEN

S. W. WEEKS, G. C. SANDER and J.-Y. PARLANGE: $n$-dimensional first integral and similarity solutions for two-phase flow 
XIANZHANG WEN and ZHICHENG WANG: Global attractivity of the periodic Kolmogorov system

N. S. WITTE, P. J. FORRESTER and CHRISTOPHER M. COSGROVE: Integrability, random matrices and Painlevé transcendents

HANZHONG WU: A variation-of-constants formula for a linear abstract evolution equation in Hilbert space

Y. F. YANG: A new trust region method for nonsmooth equations

YUNBO ZENG: See WEN-XIU MA

SONG-PING ZHU: See HUAN-WEN LIU 